\title{
Foreign Languages in Ethiopia: A heyday of French
}

\author{
Daniel Aberra
}

\begin{abstract}
This study examines the first four decades of the one-hundred-and-twenty years old sociolinguistic roles of the French language in Ethiopia. The study covers the period from 1897, when the first bilateral agreements between King Menilik and the then representative of France, Lagarde, were signed, to 1935. It is noted that in this period, which is the heyday of French in Ethiopia, missionaries from France and diplomatic relations between France and Ethiopia have played major roles in popularizing French in Ethiopia's education system and print media. The French language and culture also played pivotal roles in moulding emerging urban and elite culture in Ethiopia. French's influence may also be observed in the positive attitude, which the Ethiopian urban people have towards the language French.
\end{abstract}

Keywords: Ethiopia, French, history, education, mass media

DOI: $10.7176 / \mathrm{JCSD} / 64-01$

Publication date:May $31^{\text {st }} 2021$

\section{INTRODUCTION}

It is uncommon to observe in countries of linguistic diversity the interaction of local and foreign languages. Mapping their interactions either from the local or foreign language's perspective gives us insights into the dynamics of interactions of human languages and how each language carve out its role in these interactions in the multilingual situation. Ethiopia, a country of 110 million people located in the Horn of Africa, has its local languages numbered over eighty-five (Ado et al, 2021). Ethiopia is also the country where foreign (European and Middle-Eastern) languages such as Portuguese, Arabic, French, Italian, and English (and also Greek and Hebrew) play a significant role at one time or the other (Aberra, 1998). These languages are introduced by their speakers for various sociolinguistic functions but mainly as a medium of modern education. Ethiopia has an education system that has been practiced for a long period run by the Ethiopian Orthodox Church and fully supported by the respective community and its economy- where the church schools have been established. On the contrary, western-style education has a short history in Ethiopia (Gerencheal \& Mishra, 2019). It has been started in the early $20^{\text {th }}$ century after the opening of Menilik II school in 1908 (Ibid), "Modern education is believed to be a major factor which allows the introduction and expansion of foreign, European languages in Ethiopia" (Gerencheal \& Mishra, 2019:1431).

This study focuses on the first forty years of the one-hundred-and-twenty years old sociolinguistic roles of the French language in Ethiopia from 1897-1935. However, the roles and statuses of French changed concurrently with the following historical periods of the country (1) pre-1897; (2) 1897-1935; (3) 1936-1941; (4) 1942-1973; (5) 1974-1990; and (6) 1991 - to the present. These six periods are not only historically significant but also accompanying "major political and ideological changes affect the education system in general, the roles and statuses of foreign languages in particular” (Gerencheal \& Mishra, 2019:1432).

\section{PROPOSED METHODOLOGY:}

The study is organized as follows. In addition, to the introduction Section (1), data sources have been discussed in Section (2), literature review and a reconstructed history of the French language in Ethiopia in Section (3). Section (4) discusses the period 1897-1935-the heyday of French in terms of education, press and economy. Conclusion constitutes Section (5). The study relies on secondary literature, informal interviews, personal observation, seminar discussions, and interactions with people throughout the country. Various Ethio-France friendship centenary festival posters and booklets have also been consulted. The data from these sources are interpreted in terms of the compatible sociolinguistic frameworks, namely, the sociolinguistic typology (Stewart, 1968), perspective (Ferguson, 1996), and the description of bilingualism (Mackey, 1968).

Aberra's (1998) study of English and his theoretical frameworks were liberally followed to produce a similar comparative study. His definitions of the core concepts of sociolinguistic typology (Stewart, 1968), perspective (Ferguson, 1996), and the description of bilingualism (Mackey, 1968) are reproduced below. "A sociolinguistic typology profiles a country's languages and their functions in international relations, education, literacy, religion, and many more to describe a nation's multilingual situation. A perspective is related to the national sociolinguistic profile formula when characterizing the languages of a nation. The perspective offers a convenient way of making gross sociolinguistic comparisons and has considerable heuristic value for suggesting lines of investigation and data collection. Descriptions of bilingualism emphasize the speaker's proficiency in the second language, which is likely to be highly affected and influenced by the attitude of a bilingual speaker towards his or her second language and towards the people who speak it. Moreover, mastery of a second 
language depends, first, on the historical relationship, i.e. similarities and differences between the mother tongue and the second language, second on the motivation to learn and use the language in the given society, and third, on the contact between speakers of the two languages in areas such as the economy, administration, culture, politics, the military, and religion" (Ibid).

\section{RECONSTRUCTED HISTORY OF THE FRENCH LANGUAGE IN ETHIOPIA}

This study focuses mainly on the functional roles of the French in its hundred and twenty years of existence (1897-2019) in Ethiopia. France and Ethiopia celebrated the centennial of their diplomatic friendship in 1997. Obviously, over these years, France's culture, language, economy and policies have left their imprints on the Ethiopian urban life and culture. At the outset, it has to be noted that these are a triangulated "competition among three languages between French, English and Amharic" in the country (Sumner, 1999:8). The history and use of the French language and culture are closely intertwined with the religious, political, trade, and cultural relations between France and Ethiopia. The socio-political situations of the country and its relations with France can be reconstructed concurrently with the six noted historical periods of the country following Aberra's (1998) classification. Nevertheless, similar chronological classification is used in Gerencheal \& Mishra (2019) except the first two periods of Aberra (1998) (1) pre-1897 and period (2) 1897-1935 merged into one- "Pre-Italian Period (19001935) (2019:1432). I also believe the pre-1897 period has a different scenario, and it needs to be discussed separately.

In the Pre-1897 scenario, contact between Ethiopia and France and interest in one another started as early as 1313, though it did not come to fruition (Pankhurst, 2005). After 1855, however, King Tewodros II and his successors have established contacts with Europe, including France, to modernize the country and import goods. They lured foreigners to reside in the country and share their skills. Those who resided in the country worked in various capacities in religion, private activity, or government. Invariably, foreigners introduced their languages in $19^{\text {th }}$ century Ethiopia mainly - English, French, Arabic, and Italian - for various functions, but mainly as a medium of education; they tend to cater. Some residents, like the French poet Arthur Rimbaud, worked as sales agents and traders. The majority of the foreigners pursued predominantly (Catholic) missionary activities establishing their versions of Catholicism: the Lazarist Fathers, Capuchins of Toulouse, Brothers of the Congregation of Saint Gabriel, the Franciscan Sisters of Calais, and the Sisters of Saint Vincent of Paul are some such establishments (Alberto 1998; Pankhurst, 1997; 2005).

While citizens of these countries are involved in activities they are passionate about, Ethiopia and France signed one of the formal agreements. The signing of the first friendship agreements and trade treaty is in 1843 between King Sahle Sellassie of Shoa and the French government envoy Rochet d'Héricourt (Bureau, 1997; French Embassy website 2002/3). However, the landmark of their relations is not 1843 but the year 1897 when King Menilik of Ethiopia and the French emissary and the first ambassador Léonce Lagarde signed diplomatic, trade and cultural agreements (Bureau, 1997). Those treaties marked a transition to the second period (18971935) of their contact history.

\section{RESULT AND ANALYSIS}

By most accounts, this period (1897-1937) can be characterized as the heyday French influence in Ethiopia. The affairs they involve, Ethiopia and France, are in the area of transportation, commerce, commercial courts, religion, education and mass media. These are the areas in France's significant involvement, and influence has been noted. For instance, a railway was constructed from the former French colony of Djibouti to Addis Ababa. Foreign traders called 'tajurs.' Under the protection of France established themselves in the country. To facilitate transactions and to solve French-national involving conflicts, consular courts were created. The courts aim to ensure the proper interpretation and implementation of trade, commercial and other treaties signed between Ethiopia and France. In modern education, the French language - propelled by French missionary personnel, private French citizens, the French government, and aficionados of the French language and culture - grew in importance. French also played an important role in the emerging Ethiopian urban life during these four decades in the press, the modern economy, international relations, and modern culture and communication.

Thus, French has functioned as a second language of the state, a medium of instruction, and a school subject. Generally, in secular education, the press, and other mass communication activities such as advertising and international communication, the French language became the core medium.

As stated earlier, the French influence is significantly observed in education, the press, and the economy.

\subsection{Education}

Modern education in Ethiopia is a little older than 110 years. In October 1908, Emperor Menilik established Ecole Impérial Menilik II, Ethiopia's first government-operated, secular, western type school. In the words of Gerencheal \& Mishra (2019:1431), "the beginning of this modern education is believed as the major factor which allows the introduction and expansion of foreign (mainly European) languages in Ethiopia."

In stifling the Ethiopian Orthodox Church (EOTC), King Menilik imported Egyptian teachers with Coptic 
faith. The church was the torch-bearer, the handler of intellectual life, storehouse of knowledge, education, and runner of the justice system of the country, which may oppose the establishment of schools and modern education (run by missionaries) as the church was also a staunch opponent of Catholicism (as there had been a feud and bloodshed in the history-which involve Jesuit missionaries in the past). So the King chose and recruited Egyptian teachers with Coptic faith for a religious reason. Following the then education practice in Egypt, the language of instruction was French. It is a new subject that does not have a societal base; based on the teachers' account, and French was a popular subject. Nevertheless, in addition, students studied English, Italian and Amharic, and mathematics (Pankhurst, 1974). Other educational areas were establishing schools, using French as a medium of instruction and a school subject, and awarding scholarships for promising students to study abroad.

The elite and other communities have emulated the exemplary action of Emperor Menilik and the French community in the area of education. Fifteen to twenty government-run and private language schools were opened in Addis Ababa and other provincial cities, including Harar, Ambo, Jimma, and Selale. In particular, the Ecole Française was opened in 1912 with French as the medium of instruction (Dilebo, 1991; Pankhurst, 1974). However, schools at Asebe Teferi, Gonder, Debre Markos, Adwa and Mekele used English as the medium of instruction (Pankhurst, 1976).

An unprecedented educational advance in the history of the country marked the last decade of the period. Seven more government schools, including Lycée, were set up in the capital. The Lycée (1930) was designed to give technical and linguistic training to about a hundred students. Instruction was in French, and the subjects included modern languages (Pankhurst, 1974). Moreover, in the mid-1920s, Teferi Mekonnen School was inaugurated, with an approach markedly more French-oriented than English. Foreign languages such as French, English, and Arabic were included as subjects, and its students sat annually for the French government's examination of competency in primary studies (Pankhurst, 1974). Successive French principals ran the school. Ethiopian teachers were also part of the school teaching Amharic and elementary French.

On the other hand, a decade before 1935, movements to stifle the popular French language by instituting the rival language, English as a foreign language, had been noted (Pankhurst, 1976; Zewde 2002). People who favoured either France or Britain intervened at one time or another to reverse adverse situations for their favoured languages in the school arena. Guebre Hiwot Baykedagne (a famous writer and thinker of the time with an English education background), who was pro-English, and Andre Jarosseau (who was the private mentor of Emperor Haile Sellassie), who was pro-French, can be cited as spear-headers, of the cases in point (Eshete, 1974; Pankhurst, 2005). Andre Jarosseau went beyond supporting the French. He can be safely called the advocate of all French interests (see Zewde (2002) for some of Jarosseau's dramatic interventions on behalf of French). Eshete (1974: 30) envisaged the language use scenario of the period, stating that when King Menilik became Emperor, the European language at the Imperial Court and diplomacy became French. This French role remained the position up to 1935, the eve of the Italian annexation of Ethiopia. All told, before the Italian invasion in 1936, about thirteen schools had been established. Some of these schools used English as the language of instruction, while others used French (Markakis, 1974).

Regarding scholarships, the largest Ethiopian contingents who went abroad by various means went mainly to France and Lebanon. Eighteen were stationed in France at St. Michael College in Marseilles. Most of these students later devoted themselves to seminary work, except for one of the returnees, Grazmach Joseph, who became a prominent official for Emperor Menilik II. Scores of youngsters were also taken to different countries by missionaries (Pankhurst 1974; Pankhurst 2005). Sylvia Pankhurst (1955) estimated the number of students who studied abroad to be about forty in 1935. Those students who went to France had been first acclimatized to French culture at Alexandria Lycée in Egypt.

In conclusion, the idea of modern secular education in a foreign language was important not only to Europeans or the Ethiopian government, which look for functionaries, but also to the Ethiopian intelligentsia. The intelligentsia thought it was key to maintaining sovereignty and developing the nation, believing that understanding a foreign language facilitated the transfer of modern knowledge and transfer of technical knowhow necessary for Ethiopia's survival in the modern world. For instance, Baykedagne proposed a modern system of education in which the teaching of foreign and local languages would constitute part of the curriculum towards this end (Aberra, 1998). By and large, modern education produced functionaries and intellectuals. Interestingly, Zewde (1991) noted a trend in which functionaries were trained in the country while the intellectuals were trained abroad.

\subsection{Press}

The second noticeable involvement of the French language is in the area of the press. Press activities of the period (1897-1935) comprised two entities: the establishment of religious printing presses and establishments of newspapers in the capital city, Addis Ababa, Harar, and Dire Dawa. The first weekly bilingual newspaper was created by the French monks (Gartley, 1994). It was Father Marie Bernard, a Franciscan missionary, who began publishing Le Semeur Ethiopie. He also published 'The Bulletin de la Léproserie de Harar,' a French and Amharic weekly paper, at 
Harar between 1900-1915 (Bureau, 1997; G. Tsadik,1998). Father Bernard, moreover, securing Emperor Menilik's acknowledgment, expanded his operations into commercial printing by using a duplicating machine Roneograph (Bonsa, 2000). The profits from this venture were used to finance St. Anthony's Leprosy Center. Bekele (1982:207), on the other hand, reported that Le Semeur d' Capucin missionaries published Ethiopie, a monthly magazine, in Dire Dawa since 1905. It continued until 1914, when the French monks were called back.

Activities of the press include the establishment of printing presses in Dire Dawa, publishing and printing many pedagogical, liturgical, catechetical, and devotional books in French and local languages. It prospered until 1935, the time of the Italian occupation. The Italians took control of it afterwards (Alberto, 1998). In another instance of the press activities, Pankhurst (1955:524-528) enumerated the expansion of the press in Ethiopia, where the impact of French and France were observed. Many small hand presses were being imported into the towns of Ethiopia from various European countries. The French Lazarist fathers undertook a second missionary printing venture, which installed a printing press in January 1879 (G. Tsadik, 1998). One of these printing presses was responsible for printing the weekly journal Le Courrier Ethiopia (1913-1936). The founder and editor of the journal until 1924 was Alexis Desvages. He came to Ethiopia "en 1910 alors que la compagnie franco-ethiopienne du chemin de fer de Djibouti a Addis Abeba" (Rouaud, 1994:713). When Desvages liquidated the business and returned to France, Leon de Robilland took the entire responsibility for it; his daughter Germaine de Robilland served as the editor-in-chief until 1936 (Bureau, 1997; Rouaud, 1994). By Bureau's (1997) and Rouaud's (1994) accounts, Le Courrier d'Ethiopie was at first printed only in French as "a four-page four-column newspaper sold for un quart de thaler, soit $1 \mathrm{fr}$. 50". Advertisements and notices in Amharic were included later. It is said to have had a circulation of 700 initially. This was followed by what Rouaud wrote, "Le Courrier d'Ethiopie trait regulierement a 2500 exemplaires ecrit - ilbien que nous ne fussons que 300 francais et ceci in di que l'importance prise par la diffusion de notre langue chez les indigenes. At that time, French advertisements and notices were also common in other newspapers in Ethiopia" (Bureau, 1997; Dubois, 2005).

In the years following, an Ethiopian press rapidly took shape, a growing number of periodical publications issued in Addis Ababa in Arabic, English, French and Italian. The Ethiopian press as a whole was steadily growing. For instance, Le Courrier d'Ethiopie increased to 10 pages from the earlier mentioned four. Two more newspapers were then founded. One was La Revue Radio National, a French newspaper publishing current news transmitted from Europe by radio.

In addition to newspapers, books in French, an Amharic grammar book by the Lazarist missionary, "Jospeh Baeteman," and a French-Amharic and Amharic-French Dictionary by the same author has also been printed and published at the Des Vages printing press mainly between 1923 and 1929. Another monthly magazine was also published in 1930 by Weizinger. It consisted of articles in numerous European languages in addition to a section for Amharic articles. This magazine had a circulation of 2,000 copies by 1932 when publication ceased.

To conclude, the beginning of the press and print media in Ethiopia was sporadic and foreign-inspired, catering predominantly to religious matters (Bonsa 2000).

\subsection{The Economy}

In the post-Adwa (the First Italo-Ethiopian War (1895-6)) years, political and colonial ambitions of European powers thwarted. Instead, trade and concessions were expressions of European penetration (Zewde, 1991). Europeans controlled Ethiopia's foreign trade almost completely. For a start, French traders had the upper hand as they had helped Ethiopia during the war (The Italo-Ethiopian War (1895-6). One of the two remarkable concessions signed by Menilik was the railway construction by a French company, which the government of France later took over. The construction of the railway, as noted earlier, was a major source of the penetration of the French language and culture, especially its influence on local languages at the railway line was extensive (Dubois, 2005; Pankhurst, 2005).

Apart from Bekele (1982), Kozicki (2015) did an extensive study and published it on the railway in Ethiopia. Kozicki (2015), in his well-researched and well-narrated paper, aims "to inform the reader about the role that Franco-Ethiopian railway played in the economic and social development of that African country." He pinpointed that the railway plays an important role in "the Ethiopian economy and changing the social relations among the Ethiopian nations" (Kozicki, 2015:142).

Kozicki has articulated many aspects of the roles and effects of the railway, which was built with France's help. "The Ethiopian railway heavily influenced the economic and social development of the country for many reasons. Ethiopia ceased to be dependent on its Muslim neighbours as far as the transit of merchandise is concerned. Thanks to the Franco-Ethiopian railway, the country avoided long-term colonization and became a member of the League of Nations and, consequently, the seat of the African Unity Organization. As for the social relations of the Ethiopian nations, they changed radically as the nomadic and pastoral peoples employed at the construction of the railway changed their ways of life and conformed to the European lifestyle. What is more, the railway construction contributed to the cooperation of people diversified under the account of beliefs and cultural backgrounds who previously lived in discord" (Kozicki, 2015:168). 


\section{Conclusion}

French and English have been the main European languages used in Ethiopia. French dominated the scene, beginning with the reign of Menilik II and continuing until the first half of Haile Sellassie's reign, i.e., up to 1935. After the fierce competition between French and English and France's defeat during World War II, the French language had lost its dominant role and was supplanted by English (Aberra, 1998:115). The period (1897-1935), however, is characterized on the one hand by the intensity of use of French in Ethiopia and on the other hand by its dramatic curtailment due to the Laval-Mussolini Agreement of January 7, 1935 (Bekele, 1982); when France sided with Italy at the eve of the second major invasion of Ethiopia by Italy which lasted five years (1935-1941).

Before 1935, by and large, Emperor Haile Sellassie, other politicians and the various elites of the time had French education, mainly in France and Ethiopia. At that time, practically all the cabinet ministers speak French with one or two exceptions. In addition, many speakers of French resided in Addis Ababa. In 1935, there were 300 French citizens and 1500 people under the protectorate of the French government in the country. The majority of these 1500 people were Armenians, Lebanese, Syrians, Arabs, Somalis, Russians, Poles, Czechs and Chinese. To this list, asked Bureau, the French historian and anthropologist (1997), 'should not Greeks and Egyptians families who consider French, the language of commerce, culture and civilizations be included?'

This period is construed as the heyday of the French in Ethiopia. It is characterized on the one hand by the intensity of the use of French in Ethiopia and, on the other, its dramatic halt due to France's decision to side with Italy. The glory and demise of the French were beautifully penned by the long-time advisor of Emperor Haile Selassie, Spencer (1984) and the history professor Bekele (1982).

The Emperor's [Haile Sellassie's] education had been in French. French remained his lingua franca. From Emperor Menilik, France had acquired a dominating cultural, economic, and diplomatic role in Ethiopia. Higher education was in French. Commercial law was in French. The one major European language newspaper, the Courrier d'Ethiopie, was in French. Diplomatic correspondence has been in French. Ethiopia's sole access to the sea is the railway from Addis Ababa to Djibouti via French Somaliland. The chemin de fer franco-ethiopien de Djibouti a Addis Abeba is a French company. France exerted a yet deeper influence. For decades, it had been Ethiopia's ally against the Anglo-Italian designs [of colonialist aspirations] in the Horn of Africa. However, the Laval-Mussolini Agreements of January 7, 1935, by which France gave Italy a free hand in Ethiopia, brought this long period of cooperation to a sudden end (Spencer, 1984).

On the other hand, the political game that Menilik played in constructing the railway ended up with an unpredicted outcome, as Bekele (1982) noted.

Menilik seems to have calculated in 1893-4 that if the railway were introduced, it would decisively bring France into his side in the impending showdown with Italy. However, on January 3, 1935, Mussolini and Laval signed an accord in which the latter ceded $10 \%$ of the company's shares [railway] to Italy. In doing so, France abandoned Ethiopia. Even the railway could not have sufficient weight to persuade France to support Ethiopia against the Fascist onslaught [of the 1935-1941 period].

\section{References}

Aberra, Daniel. (1998). 'English in the Ethiopian Modern Education (1900-1974)'. Ethiopian Journal of Languages and Literature, 8:113-146.

Ado, Derib et al. (2021).'The languages of Ethiopia: Aspects of the sociolinguistic profile' Derib Ado, Almaz W. Gelagay, and Janne B. Johannessen (eds.), Grammatical and Sociolinguistic Aspects of Ethiopian Languages, 1-12. Amsterdam/ Philadelphia: John Benjamins Publishing Company.

Alberto, Antonios. (1998). The Apostolic Vicariate of Galla, A Capuchin Mission in Ethiopia (1846-1942): Antecedents, Evolution and Problematics. Addis Ababa: Capuchin Institute of Philosophy and Theology.

Bekele, Shiferaw. (1982). 'The Railway Trade and Politics: A Historical Survey 1896-1935'. Addis Ababa: AAUDepartment of History. MA Thesis.

Bonsa, Shimelis. (2000). Survey of the Private Press in Ethiopia:1991-1999. Addis Ababa: FSS. Monograph Series 1. Bureau, Jacques. (1997). France and Ethiopia: Short Note of Hundred Years Friendship. Addis Ababa: French Embassy. CFEE.

Dilebo, Lapiso G. (1991). Feudalism and Early Capitalism in Ethiopia 1900-1966. Addis Ababa: Commercial PP. (in Amharic).

Dubois, Colette. (2005). 'French-language.' In Siegbert Uhlig (ed.). Encyclopedia Aethiopica, 2: 579-80. Wiesbaden: Harrasowitz Verlag.

Eshete, Aleme. (1974). 'The Pre-war Attempts to Promote the Use of English Language in the Educational System of Ethiopia in Place of French.' Ethiopian Journal of Education 6(2): 65-84.

Ferguson, Charles A. (1996). 'The Role of Arabic in Ethiopia: A Sociolinguistic Perspective (1970)'. In Ferguson, Charles A \& Thom Hubner (eds.). Sociolinguistic Perspectives: Papers on Language and Society, 1959-1994 Charles A. Ferguson, 48-58. Oxford: Oxford University Press. 
French Embassy in Ethiopia official website. (2002/3). /www-ambafrance-ethiopie-org/English/. French Ministry of Foreign Affairs.

Gartley, John. (1994). 'Ethiopian Educational Television in Transition;1974-90'. In Bahru Zewde, Richard

Pankhurst \& Taddese Beyene (eds.).Proceedings of the $11^{\text {th }}$ ICES, 2:599-608. Addis Ababa. Institute of Ethiopian Studies.

Gerencheal, B and Mishra, D.(2019). Foreign languages in Ethiopia: History and current status. International Journal of Research and Analytical Reviews (IJRAR), (6)1:143-1439.

G. Tsadik, Degife. (1998). 'Early Printed Books in Ethiopian Languages in Some Foreign Libraries: A Brief Survey.' A paper was presented at The First Interdisciplinary Seminar of The Institute of Ethiopian Studies held at Nazareth. June 6-7, 1998.

Kozicki, Michał. (2015). The history of the railway in Ethiopia and its role in this country's economic and social development. Studies of the Department of African Languages and Cultures, 49: 142-169.

Mackey, William F. (1968). ‘The Description of Bilingulism'. In Fishman, Joshua (ed.). Readings in the Sociology of Language, 554-584. The Hague: Mouton.

Markakis, John. (1974). Ethiopia: Anatomy of Traditional Polity._Addis Ababa: OUP.

Pankhurst, Richard. (1974). 'Education; Language and History; An Historical Background to Post-war Ethiopia' Ethiopian Journal of Education, 2(1): 75-97.

Pankhurst, Richard. (1976). 'Historical Background of Education in Ethiopia.' In Bender, M.L. et al (eds.). Language in Ethiopia, 305-323. London: OUP.

Pankhurst, Richard. (1997). ' Some Historical Notes on its Relations with Foreign Countries Prior to the Second World War: The Ethiopian Diplomatic Scene. Ethioscope, 3(2).26-32. Addis Ababa: Ministry of Foreign Affairs.

Pankhurst, Richard. (2005). 'France, relations with.' In Siegbert Uhlig (ed.), Encyclopedia Aethiopica, 2:574-77. Wiesbaden: Harrasowitz Verlag.

Pankhurst, Sylvia. (1955). Ethiopia: A Cultural History. Essex: Lalibela House.

Rouaud, Alain. (1994). 'Le Courrier d'Ethiopie (1913-1936) un journal Ethiopien en langue

Francaise' In Bahru Zewde, Richard Pankhurst \& Taddese Beyene (eds.). Proceedings of the $11^{\text {th }}$ ICES, 1:711-724. Vol.1.Addis Ababa: AAU/IES.

Spencer, John. (1984). Ethiopia at Bay: A Personal Account of the Haile Sellassie Years. Algonac: Reference Publications.

Stewart, William. (1968). 'A Sociolinguistic Typology for Describing National Multilingualism.' Fishman, J. (ed.). Readings in the Sociology of Language, 531-545. The Hague: Mouton.

Sumner, Claude. (1999). 'Ethiopian Literature and Philosophy'. Sumner, C.(ed.). Living Springs of Wisdom and Philosophy: The Ethiopian Sources of African Philosophy, 2: 3-37. Addis Ababa: Bole Printing Press.

Zewde, Bahru. (1991). A History of Modern Ethiopia, 1855-1974. Ethiopia: AAU PP.

Zewde, Bahru. (2002). Pioneers of Change in Ethiopia: The reformist intellectuals of the early twentieth century. Ohio: Ohio University Printing Press. 